\title{
Regulatory B Cells and Allergy: Uncovering the Link
}

\author{
Mota I', Martins $\mathrm{C}^{2}$, Borrego LM ${ }^{1,2}$
}

\author{
'Immunoallergy Department, CUF Descobertas Hospital, Lisbon, Portugal \\ ${ }^{2}$ CEDOC, Chronic Diseases Research Center, Immunology, NOVA Medical School|FCM, Universidade Nova de \\ Lisboa, Lisbon, Portugal
}

J Investig Allergol Clin Immunol 2017; Vol. 27(4): 204-212

doi: 10.18176/jiaci.0157

\section{Abstract}

Regulatory B (Breg) cells are recognized as immunosuppressive cells. During the last few years, several subsets of Breg cells with different phenotypes and suppressive mechanisms have been described in the literature. We review the role of Breg cells in allergy based on an extensive literature search in PubMed.

We describe the types and mechanisms of action of B cells and their role in the pathogenesis of several allergic diseases (allergic asthma, allergic rhinitis, food allergy, contact hypersensitivity, and anaphylaxis).

Key words: Regulatory B cells. Allergy. Allergic disease. Allergen tolerance. B10. Br1. Asthma. Food allergy. Hymenoptera venom allergy. Pregnancy.

\section{Resumen}

Los linfocitos reguladores del tipo B (B reg.) juegan un papel importante en el funcionamiento del sistema inmunitario. Durante los últimos años, se han descrito varios subgrupos de linfocitos B reg., con diferentes fenotipos y mecanismos supresores. Nuestro objetivo es recopilar la información existente sobre el papel de los linfocitos B reg. en Alergología, en base a una profunda investigación bibliográfica en PubMed. Describimos los tipos y mecanismos de acción de los linfocitos B y su función en la patogénesis de varias enfermedades alérgicas (asma alérgica, rinitis alérgica, alergia alimentaria, eccema de contacto y anafilaxia).

Palabras clave: Linfocitos B reguladores. Alergia. Enfermedad alérgica. Tolerancia a alérgenos. B10. Br1. Asma. Alergia alimentaria. Alergia al veneno de himenópteros. Embarazo. 


\section{Introduction}

Regulatory cells are essential for preserving immune homeostasis and self-tolerance. Research has focused primarily on the role of $\mathrm{CD} 4^{+} \mathrm{CD} 25^{+} \mathrm{Foxp}^{+}$regulatory $\mathrm{T}$ (Treg) cells, whose role in the pathogenesis of autoimmune and allergic diseases has been extensively studied, as has their role in the maintenance of tolerance to allergens [1-5]. Compared with $\mathrm{T}$ cells, or even with dendritic cells, the role of $\mathrm{B}$ cells in immune regulation has received little attention.

Evidence supporting the regulatory function of B cells has been accumulated over the last 20 years, mainly in animal models. In 1996, compelling data in this field were reported by Wolf et al [6], who induced experimental autoimmune encephalomyelitis in genetically B cell-deficient mice. Afterwards, in 2002, using animal models of intestinal inflammation, Mizoguchi et al [7] demonstrated that a B-cell subset, CD1d ${ }^{\text {hi }}$, which produced interleukin-10 (IL-10), could suppress the progression of intestinal inflammation. At same time, Fillatreau et al [8] showed that IL-10 produced by B cells plays a key role in controlling autoimmunity. These studies have put forward the concept of a specific regulatory B cell (Breg) subset that produces IL-10. Lately, several other studies have reported a significant role for B cells in suppressing allergic and autoimmune responses.

This paper focuses on the role of Breg cells in allergy. We describe the types and mechanisms of action of B cells and their role in the pathogenesis of several allergic diseases (allergic

Table. Historic Perspective and Phenotypic Characterization of Human and Mice Breg Cell Subsets (Adapted From van de Veen [12])

\begin{tabular}{|c|c|c|c|}
\hline Model & Date & Phenotype (Designation) & Associations \\
\hline \multirow[t]{8}{*}{ Human } & 2008 & $\mathrm{C} 1 \mathrm{~d}^{\mathrm{hi}}$ & MS [57], CHB, CHC [58] \\
\hline & $2010-12$ & $\mathrm{CD} 19^{+} \mathrm{CD} 24^{\mathrm{hi}} \mathrm{CD} 38^{\mathrm{hi}}$ (immature cells) & SLE, RA [34], CHB [59] \\
\hline & 2011 & $\mathrm{CD} 27^{+} \mathrm{CD} 24^{\mathrm{hi}} \mathrm{CD} 148^{\mathrm{hi}} \mathrm{CD} 48^{\mathrm{hi}}(\mathrm{B} 10$ cells $)$ & $\begin{array}{l}\text { RA, SLE, SS, autoimmune vesiculobullous skin } \\
\text { disease, MS (higher levels than healthy controls) [60] }\end{array}$ \\
\hline & 2013 & $\begin{array}{l}\mathrm{CD} 73-\mathrm{CD} 25^{+} \mathrm{CD}^{-} 1^{+} \\
(\mathrm{Br} 1 \text { cells })\end{array}$ & $\begin{array}{l}\text { Nonallergic beekeepers and patients receiving } \\
\text { allergen-specific immunotherapy (allergen tolerance) [47] }\end{array}$ \\
\hline & 2014 & $\mathrm{CD} 27^{\text {int }} \mathrm{CD} 38^{+}$(plasmablast) & $\begin{array}{l}\text { Healthy donors (regulatory role in autoimmune } \\
\text { inflammation) [61] }\end{array}$ \\
\hline & 2014 & $\mathrm{CD} 19^{+} \mathrm{CD} 25^{+}$ & MS [62] \\
\hline & 2015 & $\mathrm{CD} 5^{+} \mathrm{CD} 24^{\mathrm{hi}} \mathrm{CD} 38^{\mathrm{hi}}$ & ANCA-associated vasculitis [63] \\
\hline & 2013-15 & $\mathrm{CD} 19^{+} \mathrm{CD} 24^{\mathrm{hi}} \mathrm{CD} 38^{\mathrm{hi}}$ & ITP [64], pemphigus [65], RA [66], SS [67] \\
\hline \multirow[t]{11}{*}{ Mice } & 2002,2013 & $\begin{array}{l}\mathrm{IgM}^{\mathrm{hi}} \mathrm{CD}^{+} \mathrm{CD} 1 \mathrm{~d}^{\text {hi }} \mathrm{FasL}^{+} \\
\text {(killer B1a cells) }\end{array}$ & Schistosoma mansoni infection $[68,69]$ \\
\hline & 2007-08 & $\mathrm{CD} 19^{+} \mathrm{CD}^{+}(\mathrm{B} 1 \mathrm{a}$ cells $)$ & Neonatal acute inflammation [70], chronic colitis [71] \\
\hline & $2008-2015$ & $\mathrm{CD}_{19}{ }^{+} \mathrm{CD} 1 \mathrm{~d}^{\mathrm{hi}} \mathrm{CD}^{+}(\mathrm{B} 10$ cells $)$ & $\begin{array}{l}\text { Contact hypersensitivity [72], EAE [73], lupus [74], } \\
\text { EAMG [75], collagen-induced arthritis [76], } \\
\text { colitis [77], allergic airway inflammation }[21,24]\end{array}$ \\
\hline & 2013 & Tolerogenic $\mathrm{CX} 3 \mathrm{CR} 1^{+} \mathrm{B}$ cells & Food allergy-induced intestinal inflammation [46] \\
\hline & $2007,2009,2015$ & $\begin{array}{l}\mathrm{CD} 19^{+} \mathrm{CD} 21^{\mathrm{hi}} \mathrm{CD} 23^{\mathrm{hi}} \\
\mathrm{CD} 24^{\mathrm{hi}} I g M^{\mathrm{hi}} I_{g D}^{\mathrm{hi}} \mathrm{CD} 1 \mathrm{~d}^{\mathrm{hi}} \\
\text { (transitional type } 2 \text { B cells) }\end{array}$ & $\begin{array}{l}\text { Experimental arthritis [78], lupus [79], } \\
\text { tolerance induction and allograft survival [80] }\end{array}$ \\
\hline & 2009 & $\begin{array}{l}\mathrm{B} 220^{+} \mathrm{CD} 21^{+} \mathrm{CD} 22^{+} \mathrm{CD} 23^{+} \mathrm{CD} 24^{+} \\
\mathrm{CD} 1 \mathrm{~d}^{+} \mathrm{CD} 138^{+} \mathrm{IgD}^{+} \mathrm{IgM}^{+} \\
\text {(GIFT-15 B cells) }\end{array}$ & EAE [81] \\
\hline & 2012 & $\mathrm{CD} 24^{\mathrm{hi}} \operatorname{Ig} \mathrm{M}^{\mathrm{hi}} \operatorname{Ig} \mathrm{D}^{\mathrm{lo}} \mathrm{CD} 1 \mathrm{~d}^{\text {hi }}(\mathrm{MZ}$ B cells) & Leishmania donovani infection [82] \\
\hline & 2016 & $\mathrm{CD} 19^{+} \mathrm{CD} 21^{\mathrm{hi}} \mathrm{CD} 23^{-}(\mathrm{MZ}$ precursor B cells $)$ & Allograft survival [83] \\
\hline & $2014-15$ & $\begin{array}{l}\text { IgM }^{+} \mathrm{CD} 138^{\text {hi TACI }}{ }^{+} \mathrm{CXCR} 4^{+} \\
\text {CD1 } \text { dint }^{\text {int }} 1^{\text {int }} \\
\text { CD138 } \\
\text { (plasma cells) }\end{array}$ & EAE, Salmonella enterica infection[84], tumors [85] \\
\hline & 2014 & CD $138^{+}$CD $44^{\text {hi }}$ (plasmablast) & EAE [61] \\
\hline & 2014-16 & IL-35+Breg (i35-Breg) & EAE [84], EUA [86-88] \\
\hline
\end{tabular}

Abbreviations: ANCA, antineutrophil cytoplasmic autoantibody; $\mathrm{CHB}$, chronic hepatitis $\mathrm{B}$; $\mathrm{CHC}$, chronic hepatitis C; EAE, experimental autoimmune encephalomyelitis; EAMG, experimental autoimmune myasthenia gravis; EAU, experimental autoimmune uveitis; GIFT15, granulocyte-macrophage colony-stimulating factor and interleukin-15 fusokine; ITP, immune thrombocytopenia; MS, multiple sclerosis; MZ, marginal zone; RA, rheumatoid arthritis; SLE, systemic lupus erythematosus; SS, Sjögren syndrome. 
asthma, allergic rhinitis, food allergy, contact hypersensitivity, and anaphylaxis).

\section{Breg Cells: Types and Mechanisms of Action and Their Role in Allergy}

Several subsets of Breg cells with different phenotypes and suppressive mechanisms have been described in both mice and humans (Table).

Murine Breg subsets, namely $\mathrm{CD}^{+} \mathrm{B} 1 \mathrm{a}$ and $\mathrm{CD}^{-} \mathrm{B} 1 \mathrm{a}$, are found mainly in the peritoneal and pleural cavities. B1a-like cells have been identified as a relevant source of IL-10. Furthermore, in mice, $\mathrm{CD}^{+} \mathrm{CD} 1 \mathrm{~d}^{\text {hi }}$ (B10) cells have been identified. These share some characteristics with B1a $B$ cells and with other B-cell subsets. Other phenotypes of Breg resembling B2 B cells have been described. B2 cells can be divided into follicular B cells, which are found in the bloodstream and in secondary lymphoid tissues, and marginal zone (MZ) B cells. Follicular and MZ B cells originate in immature precursors in bone marrow called transitional $\mathrm{B}$ cells. In mice, both transitional MZ precursor B cells $\left(\mathrm{CD} 19^{+} \mathrm{CD} 21^{\text {hi }} \mathrm{CD} 23^{\text {hi }} \mathrm{CD} 24^{\text {hi }} \operatorname{IgM}^{\mathrm{hi}} \operatorname{IgD}^{\text {hi }} \mathrm{CD} 1 \mathrm{~d}^{\text {hi }}\right)$ and $\mathrm{MZ}$ $\mathrm{B}$ cells $\left(\mathrm{CD} 19^{+} \mathrm{CD} 21^{\text {hi }} \mathrm{CD} 23^{-} \mathrm{CD} 24^{\text {hi }} \operatorname{IgM}^{\mathrm{hi}} \operatorname{IgD}^{\mathrm{lo}} \mathrm{CD} 1 \mathrm{~d}^{\text {hi }}\right)$ have been associated with IL-10-mediated immunoregulatory functions. Briefly, in mice, the several types of Breg cells described include transitional $2 \mathrm{MZ}$ precursor (T2-MZP) cells, $\mathrm{CD}^{+} \mathrm{CD} 1 \mathrm{~d}^{\text {hi }} \mathrm{B}(\mathrm{B} 10)$ cells, MZ B cells, CD138 ${ }^{+}$plasma cells, and plasmablasts [9]. Phenotypically, murine B10 cells secrete IL-10 and are characterized by expression of CD5 and CD1d. In fact, both B10 cells and splenic T2-MZP inhibit immune responses through the production of IL-10 [10].

In humans, several B-cell subsets have been described as having regulatory capacities. The 2 main populations identified are $\mathrm{CD} 19^{+} \mathrm{CD} 24 \mathrm{hiCD} 38 \mathrm{hiCD} 1 \mathrm{~d}^{\text {hi }}$ and $\mathrm{CD} 19^{+} \mathrm{CD} 24 \mathrm{hiCD} 27^{+}$ Breg cells. The most common definition of Breg cells, however, includes cells with the phenotype $\mathrm{CD} 19^{+} \mathrm{CD} 38^{+} \mathrm{CD} 24^{+}$and intracellular IL-10 expression [11] in immature transitional B cells. Human Br1 cells are characterized by a CD73 $\mathrm{CD} 25^{+} \mathrm{CD} 71^{+}$phenotype and have been studied in the context of allergen tolerance induction [12]. Functionally, Br1 and B10 cells are IL-10-producing Breg cells, and both nomenclatures are used in the literature.

The "hygiene hypothesis" postulated by Strachan [13], states that the increasingly clean and sterile environment of modern life has promoted the development of many diseases, including asthma. Subsequent substantial evidence has supported this theory [14]. During the last few decades, lifestyle changes have transformed the nonharmful coexistence with our commensal microbiome, leading to a loss of opportunities to acquire microorganisms considered "microbial friends". Some of these organisms have beneficial properties [15]. According to this hypothesis, the loss of exposure to microorganisms increases the prevalence of many diseases such as asthma [14].

Epidemiological studies have reported an inverse association between parasitic infections, which are extremely prevalent in developing countries, and allergic disorders [16,17]. Helminth infections induce strong $\mathrm{T}_{\mathrm{H}} 2$ responses and $\mathrm{IgE}$ production. The incidence of allergic disorders is lower in individuals infected by helminths than among noninfected individuals [17]. Moreover, Breg cell production might be induced by bacterial or parasitic infections [12].

Breg cells that are induced by helminths are typically from the $\mathrm{CD}^{+} \mathrm{CD} 1 \mathrm{~d}^{\text {hi }} \mathrm{B} 10$ subset, and their effect is mostly mediated through secretion of IL-10 [12]. Additionally, other types of Bregs can be induced in helminth infection. The follicular $\mathrm{CD} 19^{+} \mathrm{CD} 23^{\text {hi }} \mathrm{B}$-cell subset might also suppress inflammatory responses. Adoptive transfer of these cells strongly suppresses allergic airway inflammation in an ovalbumin-sensitized mice model [12].

An in vitro culture system showed that Schistosoma mansoni induces IL-10-producing CD1d ${ }^{\text {hi }}$ Breg cells and that the transfer of this Breg subset suppresses allergic airway inflammation in ovalbumin-sensitized mice [17]. These findings suggest that helminthic infections have a direct impact on Breg cell function.

Infection with $S$ mansoni has been associated with high levels of IL-10 - and TGF- $\beta 1$-producing B cells that can inhibit the production of IL-4, IFN- $\gamma$, and IL-17 by T cells and mediate conversion of effector T cells into CD $25^{\text {hi }}$ Foxp $3^{+}$ IL-10-producing Treg cells. Thus, helminth infections can contribute to an immunoregulatory environment and promote both dampening of $\mathrm{T}_{\mathrm{H}} 1-, \mathrm{T}_{\mathrm{H}} 17$,- and $\mathrm{T}_{\mathrm{H}} 2$-skewed diseases [12]. Infection with $S$ mansoni proved to be protective in an experimental model of systemic anaphylaxis [18]. This effect was dependent on induction of IL-10-producing B cells, which increased 2-fold in $S$ mansoni-infected mice and can protect against allergic hypersensitivity [18]. These data illustrate the delicate balance between protective regulatory (IL-10) responses mediated by parasite induction and harmful (IL-4) allergic responses [18].

Thus, the capacity of Breg cells to suppress allergic airway inflammation seems to depend on the expression of CD1d, particularly in mice, but also presents an IL-10 dependent mechanism [7,19-21]. Studies performed by van der Vlugt $[16,22]$ have shown that schistosomes induce regulatory responses in both human and mouse CD1d ${ }^{\text {hi }} \mathrm{B}$ cells and that they can restore allergic inflammation by production of IL- 10 . Compared with uninfected children, Schistosoma-infected children overexpressed CD1 $\mathrm{d}^{\text {hi }} \mathrm{B}$ cells in peripheral blood, which in turn produced higher levels of IL-10 [16].

The recognition of microbial antigens through toll-like receptors (TLR) and the TLR signal mediator MyD88 induces B cells, which can suppress inflammation during microbial infection. Several animal and human studies have demonstrated the protective role of TLR activation (by parasites and other microbes) against allergy [23]. Infection with parasites promotes the development of Breg cells and protects from allergic inflammation [16,17]. Accordingly, animal models with B-cell-specific deficiency in both TLR2 and TLR4 developed a chronic form of experimental autoimmune encephalomyelitis, similar to chimeric models with IL-10-deficient B cells [23]. Microarray analysis of $\mathrm{CD} 19^{+} \mathrm{CD} 1 \mathrm{~d}^{\text {hi }}$ Breg cells from mice infected with $\mathrm{S}$ mansoni demonstrated increased expression of TLR7 [24]. The activation of the TLR7 pathway in $\mathrm{CD} 19^{+} \mathrm{CD} 1 \mathrm{~d}^{\text {hi }} \mathrm{B}$ cells increases their capacity to produce IL-10. The adoptive transfer of TLR7-elicited CD $19^{+} \mathrm{CD} 1 \mathrm{~d}^{\text {hi }} \mathrm{B}$ cells could reduce airway inflammation and was associated with 
airway hyperresponsiveness. TLR7 stimulation leads to the expansion of IL-10-producing CD $19^{+} \mathrm{CD} 1 \mathrm{~d}^{\text {hi }} \mathrm{B}$ cells, which can suppress allergic lung inflammation through induction of Treg cells [24].

Breg cells induce pulmonary infiltration of Treg cells independently of transforming growth factor (TGF)- $\beta$, leading to suppression of allergic airway inflammation [21]. Breg cells generated ex vivo also suppressed the development of allergic airway inflammation. Furthermore, the transfer of these regulatory B cells reversed established airway inflammation in sensitized mice [21]. Helminth-induced Breg cells were able to suppress $\mathrm{TH} 2$ cells and induce Treg cells, which further inhibited the $\mathrm{T}_{\mathrm{H}} 2$ response during allergic inflammation $[21,25,26]$.

Specific immunotherapy has proven to induce allergenspecific expansion of Breg cells, thus supporting their role in the establishment of allergen tolerance. The regulatory functions of B cells are not exclusively IL-10-dependent, and other regulatory mechanisms mediated by $\mathrm{B}$ cells include production of TGF- $\beta$, promotion of T-cell apoptosis by Fas-Fas ligand and granzyme-B pathways, and the capacity to produce inhibitory IgG4 and sialylated $\mathrm{IgG}$, both of which are able to mediate anti-inflammatory mechanisms $[3,23,26]$. Therefore, Breg cells are regarded as interesting targets for the development of new therapies to induce allergen tolerance.

\section{Allergic Asthma}

Animal studies have demonstrated that IL-10-producing B cells can modulate T-cell responses by induction of IL-10-producing T cells and Foxp $3{ }^{+}$Treg cells $[25,27,28]$. The CD $24^{\text {hi }} \mathrm{CD} 27^{+}$ Breg subset is responsible for the induction of $\mathrm{IL}-10^{+} \mathrm{CD} 4^{+} \mathrm{T}$ cells. Breg cell counts were significantly reduced in patients with allergic asthma, who also had a lower capacity to produce IL-10 in response to lipopolysaccharide. Besides the lower numbers of $\mathrm{CD} 24^{\mathrm{hi}} \mathrm{CD} 27^{+} \mathrm{B}$ cells, asthmatic patients also had lower IL-10 production by T- and B-cell coculture in response to house dust mite. This impaired regulatory activity, particularly that of $\mathrm{CD} 24^{\mathrm{hi}} \mathrm{CD} 27^{+} \mathrm{B}$ cells to induce IL- $10^{+} \mathrm{T}$ cells, supports the idea of a weakened Breg function in patients with allergic asthma [29].

Deeper analysis of the Breg phenotype has revealed that CD9 is a specific marker for Breg cells in mice and humans [30,31]. In humans, the expression of CD9 is increased dramatically at the surface of $\mathrm{CD} 24^{\mathrm{hi}} \mathrm{CD} 38^{\mathrm{hi}}$ immature B cells, which have been described as an important IL-10-secreting Breg subset able to control T-cell inflammation [32-34]. Recently, Braza et al [30] showed that this new regulatory B-cell subset, $\mathrm{CD}^{+}$ Breg cells, inhibits house dust mite-induced allergic airway inflammation. Initially, the authors showed that the induction of allergic asthma alters the homeostasis of IL- $10^{+}$Breg cells, thus increasing production of inflammatory cytokines by B cells. The frequency of IL- $10^{+}$Breg cells was decreased in the spleen and lungs of asthmatic mice. Moreover, the adoptive transfer of $\mathrm{CD}^{+} \mathrm{B}$ cells normalized airway inflammation and lung function by inhibiting $\mathrm{T}_{\mathrm{H}} 2$ - and $\mathrm{T}_{\mathrm{H}} 17$-driven inflammation in an IL-10-dependent manner, restoring a favorable immunological balance in lung tissues. Interestingly, the adoptive transfer of $\mathrm{CD}^{+}$Breg cells controlled the expansion of lung effector
$\mathrm{T}$ cells, resulting in a higher local regulatory/effector T-cell ratio. Thus, $\mathrm{CD}^{+}$Breg cells may prevent the development of asthma by inhibiting allergic airway inflammation via IL-10-dependent mechanisms and likely contribute to induction of immunological tolerance in allergic airway inflammation.

\section{Allergic Rhinitis}

Recently, Kim et al [35] found that patients with allergic rhinitis had lower levels of Breg cells than nonallergic controls [35]. The authors revealed that individuals with allergic rhinitis had significantly fewer $\mathrm{T}$ follicular helper (TFH)-like cells $\left(\mathrm{CD} 4^{+} \mathrm{PD}-1^{+} \mathrm{CXCR}^{+}\right)$and their corresponding IL-21 production than nonallergic individuals. The authors made the novel observation that Breg cells and TFH cells are both present in human lung lymph nodes. Considering that the production of Breg cells is influenced by TFH cells, the decrease in TFH-like cell counts in allergic rhinitis may contribute to the reduced numbers of Breg cells [35].

\section{Food Allergy}

In food-allergic patients, the inhibitory role of IL-10-producing $\mathrm{CD}^{+} \mathrm{B}$ cells has been described [19]. Interesting results showing the clinical relevance of B reg cells were recorded in studies on specific oral immunotherapy protocols in patients with cow's milk allergy (CMA) [36].

However, another regulatory B-cell subset that produces TGF- $\beta$ was recognized. These cells play essential roles in the induction of tolerance to non-IgE-mediated food allergy in atopic dermatitis [19]. TGF- $\beta$-producing Breg cells (Br3) were characterized in the allergic response to cow's milk [37]. Lee et al [37] performed a study with milk-allergic and milk-tolerant individuals who underwent in vitro casein stimulation and showed that $\mathrm{Br} 3$ proliferated in response to allergen stimulation in the milk-tolerant group, but not in the milk-allergic group. Hence, $\mathrm{Br} 3$ may be involved in allergy tolerance by negative regulation with TGF- $\beta$.

Noh et al [38] performed in vitro allergen (casein) stimulation of blood mononuclear cells from CMA patients and milk-tolerant individuals who had already outgrown CMA. Patients with CMA showed decreased levels of peripheral IL-10-producing regulatory B cells $(\mathrm{Br} 1)$. In response to casein stimulation, $\mathrm{Br} 1$ decreased in the CMA group and increased significantly in the milk-tolerant group. Allergen stimulation in the milk-tolerant group induced proliferation of Br1, thus suggesting a role for these cells in allergen tolerance. On the other hand, counts of apoptotic non-IL-10-producing Breg cells increased in the milk-allergic group through allergen stimulation. Considering these results, Br1 cells appear to be involved in the acquisition of immune tolerance in patients with food allergies, probably through IL-10 production [38].

Whereas oral tolerance induced by ingestion of milk alone did not improve clinical outcomes, milk intake associated with IFN- $\gamma$ injections completely suppressed the disease. Specific oral immunotherapy protocols with 
IFN- $\gamma$ have been associated with induction of tolerance in IgE-mediated food allergy $[39,40]$ and in non-IgE-mediated food allergies [40]. IFN- $\gamma$ is a representative $T_{H} 1$ cytokine, and $\mathrm{T}_{\mathrm{H}} 1 / \mathrm{T}_{\mathrm{H}} 2$ imbalance is the critical immune mechanism of allergic diseases, including food allergy [41]. IFN- $\gamma$ seems to contribute as an immunomodulatory agent with tolerogenic effects, ie, by increasing allergen-specific Br1 cells [41]. Immunotherapy with IFN- $\gamma$ was first attempted to desensitize patients with atopic dermatitis against house dust mites [42] and subsequently applied in specific oral tolerance induction (SOTI) protocols for food allergy [36]. Patients receiving IFN- $\gamma$ and milk had significantly higher proportions of $\mathrm{Br} 1$ cells after in vitro restimulation of peripheral blood mononuclear cells with casein [36]. Considering the total numbers, Br1 cells decreased following allergen stimulation before SOTI protocols, but increased after [36].

In vitro stimulation of peripheral blood mononuclear cells from milk-allergic patients (non-IgE-mediated) and milk-tolerant individuals showed that $\mathrm{Br} 1$ responses were not induced by IFN- $\gamma$ alone without casein stimulation but were induced when IFN- $\gamma$ was simultaneously administered with casein [41].

$\mathrm{Br} 3$ cells demonstrated similar responses in non-IgEmediated food allergy and proliferated in response to allergen stimulation in milk-tolerant individuals [37].

Both $\mathrm{Br} 1$ and $\mathrm{Br} 3$ cells seem to be critical for inducing immune tolerance in non-IgE-mediated food allergy related to atopic dermatitis [19].

SOTI protocols were attempted using IFN- $\gamma$ as an adjuvant in a study performed by Noh et al [39], which included 25 patients with IgE-mediated anaphylactic food allergy to milk, egg, and wheat. IFN- $\gamma$-induced SOTI was conducted in 10 patients, while 5 patients were treated only with food, 5 patients received only IFN- $\gamma$, and 5 patients did not receive any treatment. Tolerance was successfully induced in all patients with IFN- $\gamma$-induced SOTI, while no patients acquired tolerance in the control groups. Simultaneous allergen stimulation with nonspecific immunomodulation of IFN- $\gamma$ was important to achieve specific tolerance in IgE-mediated anaphylactic food allergy [39].

Kim et al [43] demonstrated that mesenteric lymph node-derived IL-10-producing $\mathrm{CD}^{+} \mathrm{B}$ cells can suppress casein-induced allergic responses in a mouse model via induction of Foxp $3^{+}$regulatory T cells in an IL-10-dependent manner. IL-10-producing $\mathrm{CD}^{+} \mathrm{B}$ cells appear to be critical for promotion of the development of oral tolerance to casein. IL-10-producing $\mathrm{CD}^{+} \mathrm{B}$ cells were increased in mesenteric lymph nodes, but not in the spleen or peritoneal cavity in casein-tolerant mice. Interestingly, previous reports had already shown that oral tolerance cannot be induced in mice lacking mesenteric lymph nodes [44,45]. Moreover, the adoptive transfer of mesenteric $\mathrm{CD}^{+} \mathrm{B}$ cells from casein-tolerant mice suppressed allergic symptoms, thus highlighting the role of this subset in induction of tolerance.

Tolerogenic B cells $\left(\mathrm{CD}^{+} \mathrm{CD} 19^{+} \mathrm{CX} 3 \mathrm{CR}^{+}\right)$comprise a specific population of Breg cells that is capable of inducing Treg cells in the intestine and suppressing food allergy-related $\mathrm{T}_{\mathrm{H}}$ 2-mediated pattern of intestinal inflammation in mice [46].

\section{Hymenoptera Venom Allergy}

IL-10-producing regulatory B cells suppress immune responses through $\mathrm{T}$ cell-dependent mechanisms. Human IL- $10^{+} \mathrm{Br} 1$ cells, namely, those with the phenotype CD73 $\mathrm{CD} 25^{+} \mathrm{CD} 71^{+}$and which are known to produce high levels of IL-10, can potently suppress antigen-specific $\mathrm{CD}^{+} \mathrm{T}$-cell proliferation [47]. In addition, IgG4 production appears to be selectively confined to human Br1 cells [47]. Concerning hymenoptera venom allergy, specific B cells for the major bee venom allergen phospholipase A2 (PLA) isolated from nonallergic beekeepers showed increased production of IL-10 and IgG4. Furthermore, the frequency of IL-10+ PLA-specific $\mathrm{B}$ cells $(\mathrm{Br} 1)$ increased in allergic patients receiving allergenspecific immunotherapy, thus supporting the concept that Breg cells are important for the establishment of allergen tolerance [47].

A recent study provided a detailed characterization of the allergen-specific B-cell response before and during bee venom immunotherapy by comparing allergic patients with healthy beekeepers before and during the beekeeping season. The authors observed that exposure to a high dose of bee venom induces similar tolerogenic B-cell responses in allergic patients and healthy beekeepers. Both groups showed increased frequencies of plasmablasts, PLA-specific memory B cells, and IL-10-secreting CD73-CD $25^{+} \mathrm{CD} 71^{+} \mathrm{Br} 1$ cells. PLA-specific IgG4-switched memory B cells expanded after exposure to bee venom. These findings suggested a similar functional immunoregulatory role for B cells in allergen tolerance in both groups [48].

\section{Contact Hypersensitivity}

The lack, or loss, of Breg cells can exacerbate symptoms of contact hypersensitivity (CHS) [10,19]. B10 cells were regarded as regulators of inflammation in murine models of CHS [11,49], which is exacerbated in CD19-deficient mice. CD19 expression is critical, and CD19 loss resulted in increased and prolonged reaction of CHS, suggesting an inhibitory role of CD19 expression in CHS [50]. Yanaba et al [51] reported the existence of a B-cell subset characterized by the phenotype $\mathrm{CD} 19^{\text {hi }} \mathrm{CD} 1 \mathrm{~d}^{\text {hi }} \mathrm{CD} 5^{+}$, which is capable of suppressing experimental induced CHS in an antigen-restricted and IL-10-dependent manner [51,52]. Adoptive transfer of this specific B-cell subset, which is derived from sensitized animals, proved to be effective in reducing inflammation in recipients sensitized with the same chemical, but not with a different one. Apparently, these data expose an underlying specificity in the Breg cell response in CHS [51,52].

\section{Pregnancy and Allergy}

Pregnancy represents an unpredictable challenge to the immune system, requiring a critical balance to assume tolerance towards the fetus without compromising immunological competence. 
A prospective observational study performed by Lima et al [53] reported that the absolute counts and percentages of most B-cell subsets were significantly lower in the third trimester of pregnancy and on the delivery day than in nonpregnant women. Moreover, the percentages of naïve $\mathrm{B}$ cells were significantly higher in the third trimester and on delivery day, and CD $24{ }^{\text {hi }} \mathrm{CD} 38^{\text {hi }}$ Breg cells were significantly higher in the postpartum [53]. These data support the idea that the peripheral $\mathrm{B}$ cell compartment undergoes quantitative changes during normal late pregnancy and postpartum.

T- and B-cell subsets are also modified in asthmatic pregnant women. Martins et al [54] reported that, in asthmatic pregnant women, CD $24{ }^{\text {hi }} \mathrm{CD} 38^{\text {hi }}$ Breg cells were decreased during pregnancy and increased significantly in the postpartum, as observed in healthy pregnant women. Similar levels of Treg cells were observed in both asthmatic and pregnant women, compared with nonpregnant women. However, Foxp3 expression in Treg cells was impaired during pregnancy in asthmatic and healthy pregnant women, recovering during the postpartum period. Although the reduction is more noticeable in healthy pregnant women than in asthmatics, both groups significantly downregulated Foxp3 expression in the third trimester of pregnancy compared with nonpregnant women. During the postpartum period, Foxp3 expression levels increased significantly in both groups. These results, which show similar patterns for Breg cells and Foxp3 expression within Treg cells, corroborate a close interaction between Treg and Breg cells in immune responses during pregnancy, which is also present in asthmatic patients.

Maternal exposure to an environment rich in microbial compounds might protect against the development of atopic sensitization [55]. It was demonstrated that in early life, immune cells preferentially produce IL-10 after stimulation with TLR ligands [56]. Accordingly, neonate mice exhibited higher levels of Breg cells than adult mice [51]. Lower TLR4-mediated IL-10 production might play a causal role in the development of atopic dermatitis in children [51]. Patients with allergic asthma showed reduced TLR4-induced IL-10 production by B10 cells when compared with healthy controls [29]. All these findings support a potential role for IL-10 Breg cells in the early control of allergic diseases. It is speculated that early exposure to pathogens can enhance the generation of Breg cells, which provide important protection against allergy, probably through the maintenance of Treg cells $[16,21,23]$.

\section{Conclusions}

There is strong evidence in favor of the prominent role of Breg cells in allergic inflammation. Moreover, human studies have found elevated levels of allergen-specific IL-10-producing Breg cells after immunotherapy, suggesting that Breg cells have a critical role in the induction of tolerance. However, further investigationsmainly human studies - are needed to clarify the exact mechanisms and the influence of Breg cells.

Large cohort studies should be performed to evaluate the impact of Breg cells on the modulation of allergic diseases.
The knowledge generated by such studies should be applied to develop targeted therapies for allergic disorders.

\section{Funding}

The authors declare that no funding was received for the present study.

\section{Conflicts of Interest}

The authors declare that they have no conflicts of interest.

\section{References}

1. Rivas MN, Chatila TA. Regulatory T cells in allergic diseases. J Allergy Clin Immunol. 2016;138:639-52.

2. Harrison OJ, Powrie FM. Regulatory $T$ cells and Immune Tolerance in the Intestine. Cold Spring Harb Perspect Biol. 2013;5:a018341:1-17.

3. Akdis CA, Akdis M. Mechanisms of allergen-specific immunotherapy and immune tolerance to allergens. World Allergy Organization Journal. 2015;8:17.

4. Goodman WA, Cooper KD, McCormick TS. Regulation Generation: The Suppressive Functions of Human Regulatory T cells. Crit Rev Immunol. 2012;32:65-79.

5. Milojevic D, Nguyen KD, Wara D, Mellins ED. Regulatory $T$ cells and their role in rheumatic diseases: a potential target for novel therapeutic development. Pediatric Rheumatology. 2008;6:20 doi:10.1186/1546-0096-6-20.

6. Wolf SD, Dittel BN, Hardardottir F, Janeway CA. Experimental autoimmune encephalomyelitis induction in genetically B celldeficient mice. J Exp Med. 1996;184:2271-8.

7. Mizoguchi A, Mizoguchi E, Takedatsu H, Blumberg RS, Bhan AK. Chronic intestinal inflammatory condition generates IL10-producing regulatory $B$ cell subset characterized by CD1d upregulation. Immunity. 2002;16:219-30.

8. Fillatreau S, Sweenie CH, McGeachy MJ, Gray D, Anderton SM. B cells regulate autoimmunity by provision of IL-10. Nat Immunol. 2002;3:944-50

9. Rosser EC, Mauri C. Regulatory B cells: origin, phenotype, and function. Immunity. 2015;42(4):607-12.

10. Bouaziz JD, Yanaba K, Tedder TF. Regulatory B cells as inhibitors of immune responses and inflammation. Immunol Rev. 2008:224:201-14

11. Mazer B. Is there a place for $B$ cells as regulators of immune tolerance in allergic diseases? Clin Exp Allergy. 2014;44:469-71.

12. van de Veen W, Stanic B, Wirz OF, Jansen K, Globinska A, Akdis $M$. Role of regulatory $B$ cells in immune tolerance to allergens and beyond. J Allergy Clin Immunol. 2016;138:654-65.

13. Strachan DP. Hay fever, hygiene, and household size. BMJ. 1989;299:1259-60.

14. Adami AJ, Bracken SJ. Breathing Better Through Bugs: Asthma and the Microbiome. Yale J Biol Med. 2016;89:309-24.

15. Blaser MJ, Falkow S. What are the consequences of the disappearing human microbiota? Nat Rev Microbiol. 2009;7:887-94.

16. van der Vlugt $L E$, Labuda $L A$, Ozir-Fazalalikhan A, Lievers E, Gloudemans AK, Liu KY, Barr TA, Sparwasser T, Boon L, Ngoa UA, Feugap EN, Adegnika AA, Kremsner PG, Gray D, Yazdanbakhsh M, Smits HH. Schistosomes induce regulatory 
features in human and mouse CD1d(hi) B cells: inhibition of allergic inflammation by $\mathrm{IL}-10$ and regulatory T cells. PLOS One. 2012;7(2):e30883.

17. Fallon PG, Mangan NE. Suppression of TH2-type allergic reactions by helminth infection. Nat Rev Immunol. 2007;7:220-30.

18. Mangan NE, Fallon RE, Smith P, van Rooijen N, McKenzie AN, Fallon PG. Helminth infection protects mice from anaphylaxis via IL-10-producing B cells. J Immunol. 2004; 173:6346-56.

19. Noh G, Lee JH. Regulatory B cells and allergic diseases. Allergy Asthma Immunol Res. 2011;3:168-77.

20. Tedder TF, Matsushita T. Regulatory B cells that produce IL-10: a breath of fresh air in allergic airway disease. J Allergy Clin Immunol. 2010;125(5):1125-7.

21. Amu S, Saunders SP, Kronenberg M, Mangan NE, Atzberger A, Fallon PG. Regulatory B cells prevent and reverse allergic airway inflammation via FoxP3-positive T regulatory cells in a murine model. J Allergy Clin Immunol 2010;125:1114-24.

22. van der Vlugt LE, Zinsou JF, Ozir-Fazalalikhan A, Kremsner PG, Yazdanbakhsh M, Adegnika AA, Smits HH. Interleukin 10 (IL10)-producing CD1dhi regulatory $B$ cells from Schistosoma haematobium-infected individuals induce IL-10-positive T cells and suppress effector T-cell cytokines. J Infect Dis. 2014;210:1207-16.

23. Braza F, Chesne J, Castagnet S, Magnan A, Brouard S. Regulatory functions of $\mathrm{B}$ cells in allergic diseases. Allergy. 2014;69(11):1454-63.

24. Khan AR, Amu S, Saunders SP, Hams E, Blackshields G, Leonard MO, Weaver CT, Sparwasser T, Sheils O, Fallon PG. Ligation of TLR7 on CD19(+) CD1d(hi) B cells suppresses allergic lung inflammation via regulatory $\mathrm{T}$ cells. Eur J Immunol. 2015;45(6):1842-54.

25. Hussaarts $L$, van der Vlugt LE, Yazdanbakhsh $M$, Smits $H H$. Regulatory B-cell induction by helminths: implications for allergic disease. J Allergy Clin Immunol. 2011;128:733-9.

26. Soyer OU, Akdis M, Ring J, Behrendt H, Crameri R, Lauener R, Akdis CA. Mechanisms of peripheral tolerance to allergens. Allergy. 2013;68(2):161-70.

27. Smits HH, Everts B, Hartgers FC, Yazdanbakhsh M. Chronic helminth infections protect against allergic diseases by active regulatory processes. Curr Allergy Asthma Rep. 2010;10:3-12.

28. Mauri C, Bosma A. Immune regulatory function of B cells. Annu Rev Immunol. 2012;30:221-41.

29. van der Vlugt $L E$, Mlejnek $E$, Ozir-Fazalalikhan $A$, Janssen Bonas M, Dijksman TR, Labuda LA, Schot R, Guigas B, Möller GM, Hiemstra PS, Yazdanbakhsh M, Smits HH. CD24(hi) CD27(+) B cells from patients with allergic asthma have impaired regulatory activity in response to lipopolysaccharide. Clin Exp Allergy. 2014;44:517-28.

30. Braza F, Chesne J, Durand M, Dirou S, Brosseau C, Mahay G, Cheminant MA, Magnan A, Brouard S. A regulatory CD9(+) B-cell subset inhibits HDM-induced allergic airway inflammation. Allergy. 2015;70(11):1421-31.

31. Candando KM, Lykken JM, Tedder TF. B10 cell regulation of health and disease. Immunol Rev. 2014;259:259-72.

32. Cherukuri $A$, Rothstein DM, Clark $B$, Carter CR, Davison A, Hernandez-Fuentes M, Hewitt E, Salama AD, Baker RJ. Immunologic human renal allograft injury associates with an altered IL-10/TNFalpha expression ratio in regulatory B cells. J Am Soc Nephrol. 2014;25:1575-85.

33. Flores-Borja F, Bosma A, Ng D, Reddy V, Ehrenstein MR, Isenberg DA, Mauri C. CD19+CD24hiCD38hi B cells maintain regulatory T cells while limiting TH1 and TH17 differentiation. Sci Transl Med. 2013;5:173ra23.

34. Blair PA, Norena LY, Flores-Borja F, Rawlings DJ, Isenberg DA, Ehrenstein MR, Mauri C. CD19(+)CD24(hi)CD38(hi) B cells exhibit regulatory capacity in healthy individuals but are functionally impaired in systemic Lupus Erythematosus patients. Immunity. 2010;32(1):129-40.

35. Kim AS, Doherty TA, Karta MR, Das S, Baum R, Rosenthal P, Beppu A, Miller M, Kurten R, Broide DH. Regulatory B cells and $T$ follicular helper cells are reduced in allergic rhinitis. J Allergy Clin Immunol. 2016;138(4):1192-5 e5.

36. Noh J, Noh G, Lee SJ, Lee JH, Kim A, Kim HS. Tolerogenic effects of interferon-gamma with induction of allergenspecific interleukin-10-producing regulatory $\mathrm{B}$ cell $(\mathrm{Br} 1)$ changes in non-IgE-mediated food allergy. Cell Immunol. 2012;273:140-9.

37. Lee JH, Noh J, Noh G, Choi WS, Cho S, Lee SS. Allergen-specific transforming growth factor- $\beta$-producing CD19(+)CD5(+) regulatory $\mathrm{B}$-cell $(\mathrm{Br} 3)$ responses in human late eczematous allergic reactions to cow's milk. J Interferon Cytokine Res. 2011;31:441-9.

38. Noh J, Lee JH, Noh G, Bang SY, Kim HS, Choi WS, Cho S, Lee SS. Characterisation of allergen-specific responses of IL-10producing regulatory B cells $(\mathrm{Br} 1)$ in Cow Milk Allergy. Cell Immunol. 2010;264:143-9.

39. Noh G, Lee SS. A pilot study of interferon-gamma-induced specific oral tolerance induction (ISOTI) for immunoglobulin E-mediated anaphylactic food allergy. J Interferon Cytokine Res. 2009;29:667-75.

40. Lee JH, Noh G, Noh J, Lee S, Choi WS, Kim HS, Lee K, Choi S, Jin $H$, Cho $S$, Lee $S$. Clinical characteristics of oral tolerance induction of IgE-mediated and non-lgE-mediated food allergy using interferon gamma. Allergy Asthma Proc. 2010;31:e 3947.

41. Lee SJ, Noh G, Lee JH. In Vitro Induction of Allergen-Specific Interleukin-10-Producing Regulatory B Cell Responses by Interferon-gamma in Non-Immunoglobulin E-Mediated Milk Allergy. Allergy Asthma Immunol Res. 2013;5(1):48-54.

42. Noh G, Lee KY. Pilot study of IFN-gamma-induced specific hyposensitization for house dust mites in atopic dermatitis: IFN-gamma-induced immune deviation as a new therapeutic concept for atopic dermatitis. Cytokine. 2000;12:472-6.

43. Kim AR, Kim HS, Kim do K, Nam ST, Kim HW, Park YH, Lee D, Lee MB, Lee JH, Kim B, Beaven MA, Kim HS, Kim YM, Choi WS. Mesenteric IL-10-producing CD5+ regulatory B cells suppress cow's milk casein-induced allergic responses in mice. Sci Rep. 2016;6:19685.

44. Spahn TW, Weiner $H L$, Rennert PD, Lügering $N$, Fontana $A$, Domschke W, Kucharzik T. Mesenteric lymph nodes are critical for the induction of high-dose oral tolerance in the absence of Peyer's patches. Eur J Immunol. 2002;32:1109-13.

45. Macpherson AJ, Smith K. Mesenteric lymph nodes at the center of immune anatomy. J Exp Med. 2006;203:497-500.

46. Liu ZQ, Wu Y, Song JP, Liu X, Liu Z, Zheng PY, Yang PC. Tolerogenic CX3CR11 B cells suppress food allergy-induced intestinal inflammation in mice. Allergy. 2013;68:1241-8. 
47. van de Veen W, Stanic B, Yaman G, Wawrzyniak M, Söllner S, Akdis DG, Rückert B, Akdis CA, Akdis M. IgG4 production is confined to human IL-10-producing regulatory B cells that suppress antigen-specific immune responses. J Allergy Clin Immunol. 2013;131:1204-12.

48. Boonpiyathad T, Meyer $N$, Moniuszko $M$, Sokolowska $M$, Eljaszewicz A, Wirz OF, Tomasiak-Lozowska MM, BodzentaLukaszyk A, Ruxrungtham $K$, van de Veen W. High-dose bee venom exposure induces similar tolerogenic B-cell responses in allergic patients and healthy beekeepers. Allergy. 2017;72(3):407-15.

49. Jin G, Hamaguchi $Y$, Matsushita $T$, Hasegawa M, Le Huu D, Ishiura N, Naka K, Hirao A, Takehara K, Fujimoto M. B-cell linker protein expression contributes to controlling allergic and autoimmune diseases by mediating IL-10 production in regulatory B cells. J Allergy Clin Immunol. 2013;131:1674-82.

50. Watanabe $R$, Fujimoto $M$, Ishiura $N$, Kuwano $Y$, Nakashima H, Yazawa N, Okochi H, Sato S, Tedder TF, Tamaki K. CD19 Expression in B Cells Is Important for Suppression of Contact Hypersensitivity. Am J Pathol. 2007;171:560-70.

51. Yanaba K, Bouaziz JD, Matsushita T, Tsubata T, Tedder TF. The development and function of regulatory B cells expressing IL-10 (B10 cells) requires antigen receptor diversity and TLR signals. J Immunol. 2009;182(12):7459-72.

52. Vitale G, Mion F, Pucillo C. Regulatory B cells: evidence, developmental origin and population diversity. Mol Immunol. 2010;48:1-8.

53. Lima J, Martins C, Leandro MJ, Nunes G, Sousa MJ, Branco $J C$, Borrego LM. Characterization of B cells in healthy pregnant women from late pregnancy to post-partum: a prospective observational study. BMC Pregnancy Childbirth. 2016;16(1):139. doi: 10.1186/s12884-016-0927-7.

54. Martins C, Lima J, Nunes G, Borrego LM. Regulatory T and $B$ cells in asthmatic women: variations from pregnancy to postpartum Treg and Breg: pregnancy to postpartum. J Investig Allergol Clin Immunol. 2016;doi: 10.18176/jiaci.0086. [Epub ahead of print].

55. Ege MJ, Bieli C, Frei R, van Strien RT, Riedler J, Ublagger E, Schram-Bijkerk $D$, Brunekreef $B$, van Hage $M$, Scheynius A, Pershagen $G$, Benz $M$, Lauener $R$, von Mutius E, BraunFahrlander tPSt. Prenatal farm exposure is related to the expression of receptors of the innate immunity and to atopic sensitization in school-age children. J Allergy Clin Immunol. 2006;117:817-23.

56. Kollmann TR, Levy O, Montgomery RR, Goriely S. Innate immune function by Toll-like receptors: distinct responses in newborns and the elderly. Immunity. 2012;37:771-83.

57. Correale J, Farez M, Razzitte G. Helminth infections associated with multiple sclerosis induce regulatory B cells. Ann Neurol. 2008;64:187-99.

58. Wang L, Qiu J, Yu L, Hu X, Zhao P, Jiang Y. Increased numbers of CD5+CD19+CD1dhighlL-10+ Bregs, CD4+Foxp3+ Tregs, CD4+CXCR5+Foxp3+ follicular regulatory T (TFR) cells in CHB or CHC patients. J Transl Med. 2014;12:251.

59. Das A, Ellis G, Pallant C, Lopes AR, Khanna P, Peppa D, Chen A, Blair P, Dusheiko G, Gill U, Kennedy PT, Brunetto M, Lampertico $P$, Mauri C, Maini MK. IL-10-producing regulatory B cells in the pathogenesis of chronic hepatitis B virus infection. I Immunol. 2012;189:3925-35.
60. Iwata Y, Matsushita T, Horikawa M, DiLillo DJ, Yanaba K, Venturi GM. Characterization of a rare IL-10-competent B-cell subset in humans that parallels mouse regulatory B10 cells. Blood. 2011:117:530-41.

61. Matsumoto M, Baba A, Yokota T, Nishikawa H, Ohkawa Y Kayama H, Kallies A, Nutt SL, Sakaguchi S, Takeda K, Kurosaki T, Baba Y. Interleukin-10-producing plasmablasts exert regulatory function in autoimmune inflammation. Immunity. 2014:41:1040-51.

62. Andres C, Tejera-Alhambra M, Alonso B, Valor L, Teijeiro R, Ramos-Medina R, Mateos D, Faure F, Sanchez-Ramon S. New regulatory CD19+CD25+ B-cell subset in clinically isolated syndrome and multiple sclerosis relapse. Changes after glucocorticoids. J Neuroimmunol. 2014;270:37-44.

63. Aybar LT, McGregor JG, Hogan SL, Hu Y, Mendoza CE, Brant EJ, Poulton CJ, Henderson CD, Falk RJ, Bunch DO. Reduced CD5+CD24hiCD38hi and interleukin 10+ regulatory B cells in active antineutrophil cytoplasmic autoantibody-associated vasculitis permit increased circulating autoantibodies. Clin Exp Immunol. 2015:180:178-88.

64. Hua F, Ji L, Zhan Y, Li F, Zou S, Chen L, Gao S, Li Y, Chen $\mathrm{H}$, Cheng Y. Aberrant frequency of IL-10-producing B cells and its association with Treg/Th17 in adult primary immune thrombocytopenia patients. Biomed Res Int. 2014;2014:571302.

65. Zhu HQ, Xu RC, Chen YY, Yuan HJ, Cao H, Zhao XQ, Zheng J, Wang Y, Pan M. Impaired function of CD19+CD24hiCD38hi regulatory B cells in patients with pemphigus. Br J Dermatol 2015:172:101-10.

66. Daien $\mathrm{Cl}$, Gailhac S, Mura T, Audo R, Combe B, Hahne M, Morel J. Regulatory B10 cells are decreased in patients with rheumatoid arthritis and are inversely correlated with disease activity. Arthritis Rheumatol. 2014;66:2037-46.

67. Furuzawa-Carballeda J, Hernandez-Molina G, Lima G, RiveraVicencio $Y$, Ferez-Blando $K$, Llorente L. Peripheral regulatory cells immunophenotyping in primary Sjogren's syndrome: a cross-sectional study. Arthritis Res Ther. 2013;15(3):R68.

68. Klinker MW, Reed TJ, Fox DA, Lundy SK. Interleukin- 5 supports the expansion of fas ligand-expressing killer $B$ cells that induce antigen-specific apoptosis of CD4(1) T cells and secrete interleukin-10. PLoS One. 2013;8:e70131.

69. Lundy SK, Boros DL. Fas ligand-expressing B-1a lymphocytes mediate CD4(1)-T-cell apoptosis during schistosomal infection: induction by interleukin 4 (IL-4) and IL-10. Infect Immun. 2002;70:812-9.

70. Zhang XM, Deriaud E, Jiao XN, Braun D, Leclerc C, Lo-Man R. Type I interferons protect neonates from acute inflammation through interleukin 10-producing B cells. J Exp Med. 2007:204:1107-18.

71. Shimomura $Y$, Mizoguchi E, Sugimoto $K$, Kibe $R$, Benno Y, Mizoguchi A, Bhan AK. Regulatory role of B-1 B cells in chronic colitis. Int Immunol 2008:20:729-37.

72. Yanaba K, Bouaziz JD, Haas KM, Poe JC, Fujimoto M, Tedder TF. A regulatory $B$ cell subset with a unique CD1dhiCD51 phenotype controls $\mathrm{T}$ cell-dependent inflammatory responses. Immunity. 2008;28:639-50.

73. Kalampokis I, Yoshizaki A, Tedder TF. IL-10-producing regulatory B cells (B10 cells) in autoimmune disease. Arthritis Res Ther. 2013;15(suppl 1):S1. 
74. Watanabe $R$, Ishiura N, Nakashima $H$, Kuwano Y, Okochi H, Tamaki K, Sato S, Tedder TF, Fujimoto M. Regulatory B cells (B10 cells) have a suppressive role in murine lupus: CD19 and B10 cell deficiency exacerbates systemic autoimmunity. J Immunol 2010;184:4801-9.

75. Sheng JR, Quan S, Soliven B. CD1d(hi)CD51 B cells expanded by GM-CSF in vivo suppress experimental autoimmune myasthenia gravis. J Immunol. 2014;193:2669-77.

76. Yang $M$, Deng J, Liu $Y, K_{0} K H$, Wang $X$, Jiao $Z$, Wang $S$, Hua Z, Sun L, Srivastava G, Lau CS, Cao X, Lu L. IL-10producing regulatory B10 cells ameliorate collagen-induced arthritis via suppressing Th17 cell generation. Am J Pathol. 2012;180:2375-85.

77. Yanaba K, Yoshizaki A, Asano Y, Kadono T, Tedder TF, Sato S. IL-10-producing regulatory B10 cells inhibit intestinal injury in a mouse model. Am J Pathol. 2011;178:735-43.

78. Evans JG, Chavez-Rueda KA, Eddaoudi A, Meyer-Bahlburg A, Rawlings DJ, Ehrenstein MR, Mauri C. Novel suppressive function of transitional 2 B cells in experimental arthritis. J Immunol. 2007;178:7868-78.

79. Blair PA, Chavez-Rueda KA, Evans JG, Shlomchik MJ, Eddaoudi A, Isenberg DA. Selective targeting of B cells with agonistic anti-CD40 is an efficacious strategy for the generation of induced regulatory T2-like B cells and for the suppression of lupus in MRL/lpr mice. J Immunol. 2009;182:3492-502.

80. Moreau A, Blair PA, Chai J-G, Ratnasothy K, Stolarczyk E, Alhabbab R, Rackham $C L$, Jones PM, Smyth L, Elgueta $R$, Howard JK, Lechler RI, Lombardi G. Transitional-2 B cells acquire regulatory function during tolerance induction and contribute to allograft survival. Eur J Immunol. 2015;45:84353.

81. Rafei M, Hsieh J, Zehntner S, Li M, Forner K, Birman E, Boivin MN, Young YK, Perreault C, Galipeau J. A granulocytemacrophage colony-stimulating factor and interleukin-15 fusokine induces a regulatory $B$ cell population with immune suppressive properties. Nat Med. 2009;15:1038-45.

82. Bankoti R, Gupta K, Levchenko A, Stager S. Marginal zone $B$ cells regulate antigen-specific $T$ cell responses during infection. J Immunol 2012;188:3961-71.
83. Lal G, Kulkarni N, Nakayama $Y$, Singh AK, Sethi A, Burrell BE, Brinkman CC, Iwami D, Zhang T, Hehlgans T, Bromberg JS. IL-10 from marginal zone precursor $B$ cells controls the differentiation of Th17, Tfh and Tfr cells in transplantation tolerance. Immunol Lett. 2016;170:52-63.

84. Shen $P$, Roch $T$, Lampropoulou $V, O^{\prime}$ Connor RA, Stervbo $U$, Hilgenberg $E$, Ries $S$, Dang VD, Jaimes $Y$, Daridon C, Li R, Jouneau L, Boudinot P, Wilantri S, Sakwa I, Miyazaki Y, Leech MD, McPherson RC, Wirtz S, Neurath M, Hoehlig K, Meinl E, Grützkau A, Grün JR, Horn K, Kühl AA, Dörner T, Bar-Or A, Kaufmann SH, Anderton SM, Fillatreau S. IL-35-producing B cells are critical regulators of immunity during autoimmune and infectious diseases. Nature. 2014;507:366-70.

85. Shalapour S, Font-Burgada J, Di Caro G, Zhong Z, SanchezLopez E, Dhar D, Willimsky G, Ammirante M, Strasner A, Hansel DE, Jamieson C, Kane CJ, Klatte T, Birner P, Kenner L, Karin M. Immunosuppressive plasma cells impede T-cell-dependent immunogenic chemotherapy. Nature. 2015;521:94-8.

86. Wang RX, Yu CR, Dambuza IM, Mahdi RM, Dolinska MB, Sergeev YV. Interleukin-35 induces regulatory B cells that suppress autoimmune disease. Nat Med. 2014;20:633-41.

87. Egwuagu CE, Yu CR. Interleukin 35-Producing B Cells (i35Breg): A New Mediator of Regulatory B-Cell Functions in CNS Autoimmune Diseases. Crit Rev Immunol. 2015;35:49-57.

88. Han J, Sun L, Fan X, Wang Z, Cheng Y, Zhu J, Jin T. Role of regulatory b cells in neuroimmunologic disorders. J Neurosci Res. 2016;94(8):693-701.

Manuscript received November 24, 2016; accepted March 22, 2017.

\section{Inês Mota}

Immunoallergy Department, CUF Descobertas Hospital R. Mário Botas, 1998-018 Lisbon, Portugal

E-mail: i.andrade.mota@gmail.com 